\title{
Photon Flux Density in the Diffraction Pattern During Scattering of $H$-polarized Photons by the Infinite Grating of Metallic Strips
}

\author{
A.V. Bezougly, O.M. Petchenko, G.O. Petchenko
}

\author{
O.M. Beketov Kharkiv National University of Urban Economy, 17, Marshal Bazhanov St., 61002 Kharkiv, Ukraine
}

(Received 16 January 2021; revised manuscript received 22 February 2021; published online 25 February 2021)

The problem of diffraction of $H$-polarized light at normal incidence on an unlimited sequence of infinitely thin metallic strips is solved. A quantum-mechanical approach to the problem of diffraction is applied. Light wave is represented as a flow of particles - photons. Probability of a photon in front of and behind the grating is described by two-dimensional psi-function - single-valued, continuous and restricted, which satisfies the two-dimensional Schrödinger equation.

A strict solution of the problem about determination of $p s i$-function of a photon dissipated by the grating is led down to the boundary Riemann-Hilbert problem. The solution is obtained in the view of the convergent infinite system of linear algebraic equations. The system is suitable for any relation between the wavelength and the period of the structure and any relation between the width of a slit and the width of a strip and is convenient for numerical calculations with the help of PC. Analysis of the expressions obtained for $p s i$-function gives the possibility to conclude the following. Photons passed through or reflected by the grating get the discrete values of momentum during the interaction with the grating and deviate at discrete angles which are determined by the obtained expressions. There are intensity maxima in the points where photons come and minima - in the points where photons do not come.

As follows from the analysis of the values of the photon momentum, the possible values of the constituent of the photon momentum perpendicular to its initial direction of motion are determined by even values of the "quantum" of momentum which magnitude is determined by the grating period. This result may be examined as a rule of selection of possible values of the perpendicular constituent of the photon momentum. As follows from numerical calculations, the diffraction maxima are located in front of a slit and have some internal structure, depending on the relation between the wavelength and the grating period. When the ratio of the wavelength to the grating period decreases, the diffraction peak turns out to be slightly modulated. When the ratio of the wavelength to the grating period is more than one, the diffraction pattern vanishes and we have homogeneous illuminance.

Keywords: Diffraction, Grating, Quantum, Psi-function, Probability Amplitude, Diffraction pattern, Photon.

DOI: $10.21272 /$ jnep.13(1).01002

PACS number: $42.25 . F x$

\section{INTRODUCTION}

There are many articles devoted to the problem of wave scattering by a flat-strip grating. This is explained by theorists' interest and a wide range of applications. In this paper, a quantum-mechanical approach to the problem is applied, light wave is represented as a flow of particles - photons. The problem of diffraction of $\mathrm{H}$-polarized photons at normal incidence of the flow on the grating of an unlimited sequence of infinitely thin metallic strips is solved. The problem of determining $\Psi$-function of the photon in front of and behind the grating is led down to the Riemann-Hilbert problem. Exact expressions for $\Psi$-function as an endless system of algebraic equations are obtained. Calculations for some values of parameters are performed. Phenomenon of diffraction of particles is discussed.

\section{PROBLEM STATEMENT}

The grating is located in the XOY plane. The width of a slit between neighboring strips equals $d$, the grating period is $l$, and thus the width of a strip equals $l-d$ (see Fig. 1). The homogeneous flux of photons falls normally onto the grating from the side of negative values of the $Z$-axis. It is necessary to define intensity of the flux (the probability density $|\Psi|^{2}$ ) of photons reflected and passed through the grating.

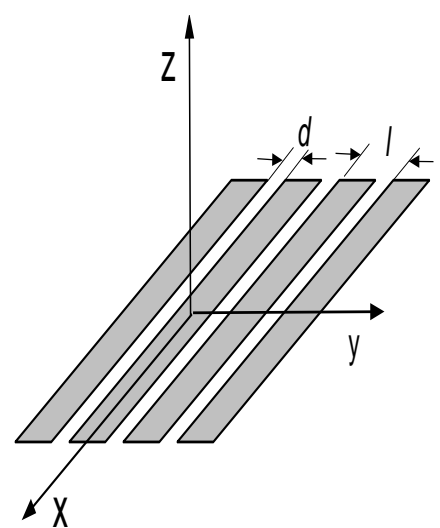

Fig. 1 - Diffraction grating

Let us represent photon $\Psi$-function as a plane de Broglie wave [1]:

$$
\Psi=H_{o} e^{-i k z}
$$

(time multiplier $e^{-i \varpi t}$ in this expression is absent, a stationary process is considered). According to the concepts of quantum mechanics, $\Psi$-function must be single-valued, continuous and restricted and have a continuous derivative, which can be easily verified by (1). In the area above $(z \leq 0)$ and under $(z \geq 0)$ the grating, $\Psi$-function of the dissipated photon must satisfy twodimensional Schrödinger equation [2] 


$$
\frac{\partial^{2} \Psi}{\partial y^{2}}+\frac{\partial^{2} \Psi}{\partial z^{2}}+2 \frac{m}{\hbar^{2}} E \Psi=0,
$$

where $E$ and $m$ are respectively the photon energy and mass. For photons, equation (2) takes the following form:

$$
\frac{\partial^{2} \Psi}{\partial y^{2}}+\frac{\partial^{2} \Psi}{\partial z^{2}}+k^{2} \Psi=0
$$

In this case, it coincides with the wave equation for electromagnetic wave: $k=2 \pi \lambda, \lambda$ is the photon wavelength. By reason of symmetry it comes out that the photon $\Psi$-function must not depend on the $X$ coordinate and, as a result of periodicity of the structure, be a periodic function of the period $l$ in the direction of the $Y$-axis. Thus, it can be decomposed into Fourier series [3]:

$$
\Psi(x, y)=\sum_{n=-\infty}^{\infty} H_{n}(z) e^{i \frac{2 \pi n}{l} y} .
$$

Let us assume that photons cannot penetrate into metallic strips. Thus, in metallic strips $\Psi \equiv 0$.

From the condition of finiteness, $\Psi$-function will have in the upper half-space the view:

$$
\begin{aligned}
& \Psi^{(I)}(y, z)=e^{-i k z}+ \\
& +\sum_{n=-\infty}^{\infty} a_{n} \exp \left(i \sqrt{k^{2}-\left(\frac{2 \pi n}{l}\right)^{2}} z\right) \cdot \exp \left(i \frac{2 \pi n}{l} y\right)
\end{aligned}
$$

In the lower half-space, the amplitude of the probability of a photon passing through the grating

$$
\begin{aligned}
& \Psi^{(I I)}(y, z)= \\
& =\sum_{n=-\infty}^{\infty} b_{n} \exp \left(-i \sqrt{k^{2}-\left(\frac{2 \pi n}{l}\right)^{2}} z\right) \cdot \exp \left(i \frac{2 \pi n}{l} y\right) .
\end{aligned}
$$

As well as in the work [4], let us consider:

$$
\gamma_{n}=\sqrt{k^{2}-\left(\frac{2 \pi n}{l}\right)^{2}}=\frac{2 \pi|n|}{l} \cdot \sqrt{\frac{\theta^{2}}{n^{2}}-1},
$$

which gives the value of the root with a positive imaginary part, and if it equals zero - a positive real part.

\section{SOLUTION OF THE PROBLEM}

In this work, we restrict ourselves to the case of $H$ polarization, when photons have only $H_{x}$-component of the magnetic field. As it follows from Maxwell electromagnetic theory [4], $\mathrm{H}$-polarized photons will have nonzero $H_{x}=\psi, E_{y}=\frac{i}{k} \frac{\partial \psi}{\partial z}$ components of the electromagnetic field. On metallic strips, $E_{y}=\frac{i}{k} \frac{\partial \psi}{\partial z}=0$, the derivative of the function is zero, and on slits, the $\Psi$-function and its derivatives are continuous. Thus, at the boundary $z=0$ we have the following conditions:

$$
\frac{\partial \psi^{(1)}}{\partial z}=\frac{\partial \psi^{(11)}}{\partial z}=0 \text { (on strips), }
$$

$$
\psi^{(1)}=\psi^{(11)}, \quad \frac{\partial \psi^{(1)}}{\partial z}=\frac{\partial \psi^{(11)}}{\partial z} \text { (on slits). }
$$

The condition (6) is carried out over the entire period of the grating. Using expressions (6), (7), at $z=0$ we obtain equalities

$$
\begin{gathered}
\beta_{o}=1-\alpha_{o}, \quad \beta_{n}=-\alpha_{n}, \\
\sum_{n=-\infty}^{\infty} \beta_{n} \exp \left(i \frac{2 \pi n}{l} y\right)=0 \text { (on strips). }
\end{gathered}
$$

Since the derivative $\frac{\partial \Psi}{\partial z}$ is continuous on slits, we also obtain the equation (on slits)

$$
-k+\sum_{n=-\infty}^{\infty} \beta_{n}\left(\sqrt{k^{2}-\left(\frac{2 \pi n}{l}\right)^{2}}\right) \cdot \exp \left(i \frac{2 \pi n}{l} y\right)=0 .
$$

Now we reduce the system of equations (9), (10) to the canonical form. First of all, using relations (10) we pass from coefficients $\beta_{n}$ to coefficients $\alpha_{n}$

$$
\begin{array}{rlrl}
\sum_{n=-\infty}^{\infty} \alpha_{n} e^{i n \phi} & =0 & \tau \prec|\varphi| \leq \pi, \\
\sum_{n=-\infty}^{\infty} \alpha_{n}|n| e^{i n \phi} & =i \theta \alpha_{0}+f\left(e^{i \phi}\right) \quad|\varphi| \prec \tau,
\end{array}
$$

where

$$
\begin{aligned}
& \theta=\frac{l}{\lambda}, \phi=\frac{2 \pi}{l} y, \xi_{n}=1+i \sqrt{\frac{\theta^{2} n^{2}}{}-1}, \\
& \tau=\frac{\pi(l-d)}{l}, f\left(e^{i \phi}\right)=-i \theta+\sum_{n \approx 0} \alpha_{n}|n| e^{i n \phi} \zeta_{n}
\end{aligned}
$$

Differentiating (11) and denoting $\alpha_{n} n=x_{n}$, we obtain

$$
\begin{gathered}
\sum_{n \neq 0} x_{n} e^{i n \phi}=0, \tau \prec|\varphi| \leq \pi \\
\sum_{n=-\infty}^{\infty} x_{n} \frac{|n|}{n} e^{i n \phi}=i \theta a_{0}+f\left(e^{i \phi}\right),|\varphi| \prec \tau
\end{gathered}
$$

Note that one additional equation must be added to these two equations, because as will be seen later, when obtaining the solution of the Riemann-Hilbert problem [4], another unknown constant appears. We get it by putting $\varphi=\pi$ in equation (14)

$$
\sum_{n \neq 0} x_{n} \frac{(-1)^{n}}{n}=-\alpha_{0}
$$

The system of equations (14), (15) forms the wellknown in the theory of diffraction of electromagnetic waves on periodic structures Riemann-Hilbert problem [4]. It is similar to the equations obtained in solving the problem of diffraction of $E$-polarized wave on a grating of infinitely thin strips with ideal conductivity. The difference is in the choice of the origin of the coordinate system. In the case of $E$-polarization, the point $y=0$ lies in the middle of the slit, and in the case of diffraction of $H$-polarized photons, the origin of the $y$-axis lies in the middle of the strip. That is, the system of equa- 
tions in the first case is written relative to the coefficients of the field behind the grating, in the second case - relative to the coefficients of expansion of the psifunction before the grating, which is dictated by the formalism of the Riemann-Hilbert problem. Equations (14), (15) are reduced to the problem, the exact solution of which is represented in the form of an infinite system of linear algebraic equations with respect to unknown coefficients $\alpha_{n}$ [4]:

$$
\begin{aligned}
& -x_{m}=i \theta \alpha_{o} V_{m}^{o}-i \theta V_{m}^{o}+\sum_{\neq \neq 0}^{\infty} x_{n} \xi_{n} \frac{|n|}{n} V_{m}^{n}+2 C R_{m} ; m \neq 0 \\
& 0=i \theta \alpha_{o} V_{o}^{o}-i \theta V_{o}^{o}+\sum_{n \neq 0} x_{n} \frac{|n|}{n} \xi_{n} V_{0}^{n}+2 C R_{0} \\
& \alpha_{0}=i \theta \alpha_{o} V_{\sigma}^{o}-i \theta V_{\sigma}^{o}+\sum_{n \neq 0} x_{n} \frac{|n|}{n} \xi_{n} V_{\sigma}^{n}+2 c R_{\sigma},
\end{aligned}
$$

where $x_{n}=n \alpha_{n}$ and expressions for the coefficients $V_{o}^{o}, V_{\sigma}^{o}, V_{\sigma}^{n}, V_{m}^{o}, V_{m}^{n}, R_{o}, R_{m}$ through Legendre polynomials are given in [6]. It is only necessary to consider the argument on which they depend on

$$
u=\cos \frac{\pi(l-d)}{l} .
$$

The infinite system of equations (17) converges at $n \rightarrow \infty$ as $1 / n^{2}$ [6] and is convenient for numerical calculations with the help of PC. At $n=$ const, $n=N$, a system of order $N+2$ with complex coefficients is extracted from the infinite system (17). In the end, we get the following expression for the probability amplitude of photons passing through the grating (considering that $\xi_{n}=\xi_{-n}, \alpha_{n}=\alpha_{-n}$ and $\left.x_{n}=x_{-n}\right)$ :

$$
\begin{aligned}
& \Psi^{(I I)}(y, z)= \\
& =\exp [-i k z] \cdot\left[b_{0}+2 \sum_{1}^{N} b_{n} \exp \left\{i\left(k-\gamma_{n}\right) z\right\} \exp (i n \phi)\right]
\end{aligned}
$$

To represent the probability amplitude in the far zone, the value $N=\theta$, which is limited in the sum of the expression (19), is sufficient. In optics, when $z / l \gg 1$, expression (19) may be represented in the form

$$
\Psi^{(I I)}(y, z)=\left[1-a_{0}+2 \sum_{1}^{N} a_{n} \cos (n \varphi)\right] .
$$

\section{DISCUSSION OF OBTAINED RESULTS}

Let us consider the phenomenon of light diffraction. First of all, this phenomenon manifests itself when light meets an obstacle on its way. So, there must be some interaction between photons and material bodies. Based on the assumption, the photon passed (or reflected) through a slit gets the component of momentum in the direction perpendicular to its primary one as a result of interaction with the obstacle-grating.

According to de Broglie [1], particles with corpuscular properties have wave properties. The rule of transition from a classical picture to a quantum one consists in that the photon has energy $E=\hbar \omega$ and momentum $p=k \hbar=2 \pi \hbar / \lambda$. Thus, for the photon reflected from or transmitted through the grating, according to (5) and (6), the following expressions can be written:

$$
\begin{gathered}
\Psi_{r}=\sum_{n=-\infty}^{\infty} a_{n} \exp \frac{i}{\hbar}\left(-p_{z} z+p_{y} y\right), \\
\Psi_{t}=\sum_{n=-\infty}^{\infty} b_{n} \exp \frac{i}{\hbar}\left(p_{z} z+p_{y} y\right),
\end{gathered}
$$

where $p_{z}, p_{y}$ are respectively the $z$ - and $y$-components of the photon momentum. In classical electrodynamics, when a plane wave falls on a grating, a diffraction field is represented as a superposition of spatial harmonics, each of them propagates at an angle, the tangent of which is determined by the relation:

$$
t q \alpha_{n}=\frac{k_{y}}{k_{z}}=\frac{2 \pi n / l}{\sqrt{k^{2}-\left(\frac{2 \pi n}{l}\right)^{2}}} .
$$
(23) as:

Using concepts of quantum mechanics, we can write

$$
t q \alpha_{n}=\frac{k_{y} \hbar}{k_{z} \hbar}=\frac{p_{y}}{p_{z}} .
$$

After simple trigonometric transformations, we get from (23) the known grating equation

$$
l \sin \alpha_{n}=n \lambda .
$$

The expression that coincides with equation (25) was also obtained in [7] when approaching narrow slits. In this case, the approach was based on the application of the laws of conservation of energy and momentum at elastic collisions of a photon with electrons. In the mentioned work [7], the diffraction pattern is explained by the fact that electrons moving in a metallic strip have discrete values of the $y$-component of the momentum. Photons passed through or reflected by the grating get the discrete values of the momentum at elastic collisions with electrons, deviate at discrete angles $\alpha_{n}$ which are determined by expressions (23)-(25). There are intensity maxima in the points where photons come, and minima - in the points where photons do not come.

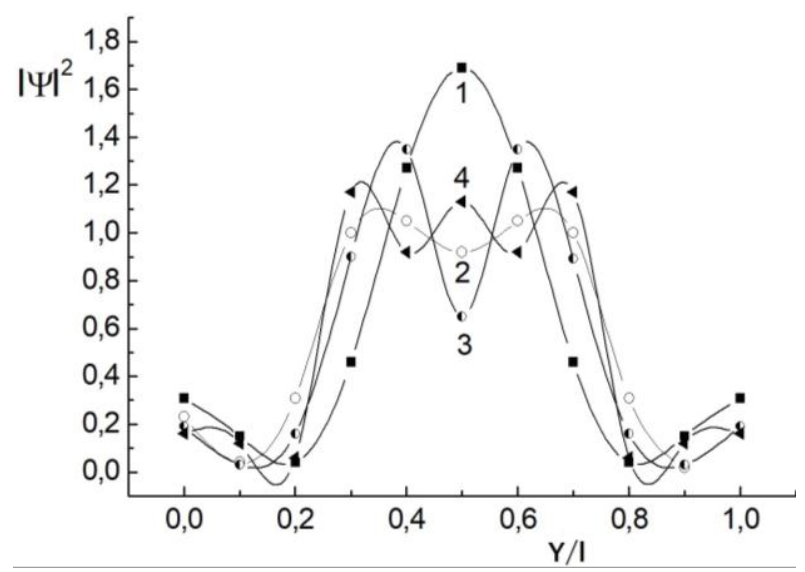

Fig. 2 - Representation of the probability distribution of photons: 1) $\theta=1.2$; 2) $\theta=2.1$; 3) $\theta=3.1$; 4) $\theta=4.1$ 
It is worth noting an interesting result following, in our view, from the analysis of the momentum $p_{y}$, which can be considered as a rule of selection of possible values of the $y$-component of the photon momentum. The latter is determined by even values of "quantum" of the momentum $\pi \hbar / l$, i.e. $p_{y}=2 \pi n / l$, where $n=0, \pm 1, \pm 2 \ldots$

The results of numerical calculations of the square module of the $\Psi$-function are shown in Fig. 2 for one period at different values of $\theta \leq 4.2$ and fill factor $d / l=0.5$, because as follows from expression (23) the diffraction pattern is repeated with the structure period $l$. As it can be seen from Fig. 2, the diffraction maximum is located in front of a slit and has some internal structure, depending on the relation between the wavelength and the grating period $\theta=l / \lambda$. As follows from expression (20), at $\theta<1$ the amplitude probability of a photon will be determined by a single term, because at $n>1$ magnitude $\gamma_{n}$ becomes imagine

$$
\Psi^{(I I)}(y, z)=\exp [-i k z] \cdot b_{0},
$$

\section{REFERENCES}

1. V.I. Vysotsky, Quantum mechanics and its use in applied physics (Kyiv: Kyiv University Printing Center Publishing House: 2008).

2. Y.I. Yukhnovsky, Foundations of quantum mechanics (Kyiv: Lybid: 2002).

3. P. Edvards, Fourier series in modern presentation (Moskva: Mir: 1985)

4. Z.S. Agranovich, V.A. Marchenko, V.P. Shestopalov, JTF 32, 381 (1962)

5. J. Jackson, Classical electrodynamics (Moskva: Mir: 1965). i.e. diffraction pattern vanishes, we have homogeneous illuminance.

\section{CONCLUSIONS}

A rigorous solution of the boundary problem by the Riemann-Hilbert method has been presented. The expressions have been obtained for the transmission amplitude and the probability of reflection of $H$-polarized photons at diffraction on an infinite grating of infinitely thin metallic strips at normal incidence for an arbitrary ratio between the width of a slit and the structure period. Unlike many published works, it has used a quantum-mechanical approach to the problem allowing a new look at the phenomenon of light diffraction. The most principal result obtained in the paper is explication of the cause of the diffraction pattern for particles which is in accordance with the theoretical [8,9] and experimental [10] results on electron diffraction.

\title{
Густина потоку фотонів на дифракційній картині при розсіюванні Н-поляризованих фотонів на нескінченній решітці з металевих смуг
}

\author{
А.В. Безуглий, О.М. Петченко, Г.О. Петченко \\ Харківський національний університет міського господарства ілені О.М. Бекетова, \\ вул. Маршала Бажанова, 17, Харків 61002, Україна
}

\begin{abstract}
Розв’язана задача про дифракцію $H$-поляризованого світла при нормальному падінні на гратку, утворену необмеженою послідовністю нескінченно тонких металевих смуг. Застосовано квантово-механічний підхід до задачі дифракції. Світлова хвиля представлена у вигляді потоку частинок - фотонів. Ймовірність фотона в області перед та за граткою описуеться двовимірною псі-функщією - однозначною, неперервною та обмеженою, яка задовольняе двовимірному рівнянню Шредінгера. Строгий розв'язок задачі про визначення псі-фоннкції фотона, розсіяного граткою, зводиться до граничної задачі Рімана-Гільберта. Розв'язок задачі отримано у вигляді нескінченної системи лінійних алгебраїчних рівнянь. Система придатна для будь-яких співвідношень між довжиною хвилі та періодом структури та будь-яких співвідношень між шириною щілини та шириною смуги, зручна для проведення чисельних розрахунків за допомогою ПК. Аналіз виразу для псі-фуункції дає можливість зробити наступний висновок. Фотони, пропущені або відбиті граткою, отримують дискретні значення імпульсу внаслідок взаємодії з граткою і відхиляються на дискретні кути від первинного напрямку. Максимуми інтенсивності на дифракційній картині з'являються в точках, куди надходять фотони, а мінімуми - в точках, куди фотони не надходять. Як випливає з аналізу значень імпульсу фотона, можливі значення складової імпульсу фотона, перпендикулярної до його початкового напрямку руху, визначаються парними значеннями "кванта" імпульсу, величина якого визначається періодом гратки. Цей результат може розглядатися як деяке правило відбору можливих значень складової імпульсу фотона. Як випливае з чисельних розрахунків, дифракційні максимуми розташовуються перед щілиною і мають деяку внутрішню структуру, залежно від співвідношення довжини хвилі та періоду гратки. При зменшенні відношення довжини хвилі до періоду гратки дифракщійний пік виявляеться злегка промодульованим. Коли відношення довжини хвилі до періоду гратки стає більше одиниці, дифракщійна картина зникає, маємо однорідну освітленість.
\end{abstract}

Ключові слова: Дифракція, Іратка, Квант, Псі-функція, Амплітуда вірогідності, Дифракційна картина, Фотон. 